\title{
Hubungan Lama Studi dengan Nilai Ujian Komprehensif Mahasiswa Program Studi Pendidikan Matematika IAIN Bukittinggi
}

\author{
Gema Hista Medika $^{{ }^{*}}$, Zebbil Billian Tomi ${ }^{2}$ \\ ${ }^{I}$ Fakultas Tarbiyah dan Ilmu Keguruan, IAIN Bukittinggi \\ ${ }^{2}$ Fakultas Matematika dan Ilmu Pengetahuan Alam, Universitas Andalas \\ Jalan Paninjauan Garegeh Bukittinggi, Sumatera Barat \\ *Email: gemahistamedika16@gmail.com
}

\author{
Article History \\ Received: 14 Mei 2020 \\ Reviewed: 22 Juni 2020 \\ Published: 30 Juni 2020

\section{Key Words \\ Length of study; \\ Comprehensive \\ examination; \\ Text score; \\ Spearman's test.}

\begin{abstract}
This study aimed to see the correlation between length of study and comprehensive test scores. This correlational study employed a quantitative approach. The population was 43 graduates of Class XI of Mathematics Education Study Program IAIN Bukittinggi in 2019. The data in this study were length of study and comprehensive test scores. The data were analyzed using the Spearman's Test because the data were not normally distributed with a significant $\alpha=5 \%$. The results showed that there was no significant correlation between length of study and comprehensive test scores with the very low category and a negative direction (sig 0.467> 0.05). Correlation value of -0.114 indicated a very low relationship with a negative direction.
\end{abstract}

\section{PENDAHULUAN}

Menurut Samekto et al., (2014), "Lama studi merupakan waktu yang dibutuhkan seorang mahasiswa untuk menyelesaikan studi di perguruan tinggi”. Sedangkan menurut Asrib \& Haedir (2017), "Masa studi merupakan rentang waktu yang disediakan bagi mahasiswa untuk menyelesaikan program pendidikan". Jadi, Lama studi adalah rentang waktu yang diperlukan mahasiswa untuk menuntaskan pendidikan di perguruan tinggi.

Berdasarkan pedoman akademik yang terdapat di Institut Agama Islam Negeri (IAIN) Bukittinggi "ujian komprehensif adalah ujian yang dilaksanakan untuk menguji pemahaman dan kemampuan teoritik mahasiswa dalam bidang keilmuan sesuai dengan prodi yang diatur sebagai berikut: (1) Ujian komprehensif dapat diikuti oleh mahasiswa yang telah lulus semua mata kuliah dan praktikum. (2) Ujian komprehensif dilaksanakan dalam satu majelis. (3) Peserta ujian komprehensif terdiri dari maksimal empat orang mahasiswa untuk setiap kelompok. (4) Materi ujian komprehensif ditetapkan oleh masing-masing fakultas sesuai dengan capaian pembelajaran dan profil lulusan. (5) Mahasiswa yang tidak lulus ujian komprehensif harus mengikuti ujian ulangan sesuai dengan jadwal. (6) Mahasiswa yang tidak lulus ujian komprehensif tidak diperkenankan mengikuti ujian skripsi” (Tim Penyusun, 2018). 
Ujian komprehensif ini mencakup tiga mata ujian, yaitu: ilmu agama islam, ilmu pendidikan dan ilmu keprodian. Dimana masingmasing persentasenya adalah: 20 persen, 30 persen dan 50 persen. Berdasarkan observasi dan data dokumen yang peneliti peroleh dari sub bagian akademik mahasiswa FTIK, ternyata tidak selalu linier antara lama studi dengan nilai komprehensif mahasiswa. Beberapa penelitian terdahulu yang membahas terkait topik ini diantaranya: Hubungan Indeks Prestasi Kumulatif dan Lama Studi dengan Nilai Uji Kompetensi Mahasiswa Program Profesi Dokter Peserta First Taker Fakultas Kedokteran Universitas Andalas, Mardi (2018) menyatakan bahwa terdapat adanya korelasi antara IPK dengan lama studi dengan nilai UKMPPD (CBT dan OSCE). Analisis Prestasi Akademik Dan Lama Studi Mahasiswa Lulusan Jurusan PMIPA FKIP UNTAN Ditinjau Dari Jalur Masuk dan Program Kuliah Djudin (2018) menyatakan bahwa terdapat hubungan antara prestasi akademik dengan lama studi mahasiswa jurusan PMIPA FKIP Untan. Hubungan Indeks Prestasi Komulatif Dengan Nilai Ujian Komprehensif Mahasiswa Fakultas Tarbiyah dan Ilmu Keguruan IAIN Bukittinggi Medika et al (2019) menyatakan bahwa terdapat hubungan antara Indeks Prestasi Komulatif dengan nilai ujian komprehensif mahasiswa Fakultas Tarbiyah dan Ilmu Keguruan IAIN Bukittinggi.

Menurut Ripkey et al (1999), kompetensi peserta didik dalam menguasai materi yang dirancang dipengaruhi oleh lamanya waktu yang digunakan untuk memproses materi tersebut, baik berupa teori ataupun praktek. Dengan kata lain, masa studi dalam penguasaan suatu materi mempengaruhi kompetensi peserta didik tersebut. Berdasarkan penjabaran di atas, penelitian ini bertujuan untuk melihat apakah terdapat hubungan/korelasi lama studi dengan nilai ujian komprehensif mahasiswa Program Studi Pendidikan Matematika IAIN Bukittinggi.

\section{METODE PENELITIAN}

Jenis penelitian adalah penelitian korelasional. Menurut Arikunto (2007) penelitian korelasional ialah penelitian yang bertujuan untuk melihat apakah terdapat hubungan antara dua atau lebih variabel. Penelitian ini bertujuan untuk melihat apakah terdapat hubungan/korelasi antara lama studi dengan nilai ujian komprehensif wisudawan/ti angkatan XI Program Studi Pendidikan Matematika IAIN Bukittinggi tahun 2019. Dimana lama studi adalah variabel bebas (X) dan variabel terikat (Y) yaitu nilai ujian komprehensif. Populasi pada penelitian ini adalah wisudawan/ti program studi pendidikan matematika IAIN Bukittinggi. Teknik pengambilan sampel yang digunakan adalah teknik purposive sampling. Menurut Sugiyono (2016), purposive sampling yaitu penelitian menentukan sampel dengan pertimbangan tertentu. Sampel pada penelitian ini adalah wisudawan/ti angkatan XI Program Studi Pendidikan Matematika IAIN Bukittinggi tahun 2019 berjumlah 43 orang. Alasan pemilihan sampel karena data terbaru dan terdapat berbagai angkatan (angkatan 2013-2015). Uji normalitas data dalam penelitian memakai uji Saphiro Wilk dimana uji hipotesis memakai Spearman's rho. Semua uji pada penelitian ini memakai software SPSS 16. Dimana bila harga uji signifikansi (sig) $\geq 0.05$ sehingga Ho diterima dan bila harga uji signifikansi (sig) $<0.05$ sehingga Ho ditolak. Arti nilai $r$ dapat dilihat dengan menggunakan tabel interpretasi nilai $r$ pada Tabel 1 (Riduwan, 2004). Teknik pengumpulan data yang dipakai pada penelitian dengan cara dokumentasi yakni lama studi dengan nilai ujian komprehensif wisudawan/ti angkatan XI Program Studi Pendidikan Matematika IAIN Bukittinggi tahun 2019.

\section{HASIL DAN PEMBAHASAN}

Sebelum penulis mencari hubungan dan membuktikan hipotesis antara lama studi dengan nilai ujian komprehensif, perlu dilakukan pengujian terhadap data. Uji normalitas data memakai uji Saphiro Wilk, sedangkan uji hipotesis memakai uji Spearman's rho.

\section{Uji Normalitas}

Berdasarkan data pada Tabel 1 mengenai hasil uji normalitas, diperoleh bahwa lama studi adalah tidak normal dimana nilai uji signifikansi $(0.000)$ < P.sig (0.05), sedangkan nilai kompre juga tidak normal dengan nilai signifikan 0.048 $<$ P.sig (0.05). Sehingga, untuk melihat hubungan/korelasi antar variabel dengan memakai uji spearman's rho.

2. Uji Hipotesis 
Analisis selanjutnya yang dilakukan adalah pengujian hipotesis penelitian. Adapun untuk uji hipotesis yaitu:

Ho : tidak ada hubungan yang signifikansi antara lama studi dan nilai ujian komprehensif wisudawan/ti angkatan XI Program Studi Pendidikan Matematika IAIN Bukittinggi tahun 2019.

Ha : ada hubungan yang signifikansi antara lama studi dan nilai ujian komprehensif wisudawan/ti angkatan XI Program Studi Pendidikan Matematika IAIN Bukittinggi tahun 2019.

Hasil uji spearman's rho terlihat pada Tabel 2. Dengan memperhatikan nilai $\operatorname{sig}(0.467)>P . \operatorname{sig}(0.05) \quad$ sehingga Ho diterima akibatnya Ha ditolak, artinya tidak ada korelasi yang signifikansi antara lama studi dan nilai ujian komprehensif wisudawan/ti angkatan XI Program Studi Pendidikan Matematika IAIN Bukittinggi tahun 2019. Pada Tabel 3 dapat dilihat interpretasi hubungan antara lama studi dan nilai kompre sebesar -0.114 yang menunjukkan hubungan yang sangat rendah. Kriteria arah hubungan dilihat pada angka koefisien korelasi menunjukkan hubungan kedua variabel tidak searah, artinya jika lama studi nilainya tinggi, maka nilai ujian komprehensif akan rendah.
Hasil yang didapat tersebut berbeda dengan hasil penelitian yang berjudul "Hubungan Indeks Prestasi Kumulatif dan Lama Studi dengan Nilai Uji Kompetensi Mahasiswa Program Profesi Dokter Peserta First Taker Fakultas Kedokteran Universitas Andalas" oleh Mardi (2018) yang menyatakan bahwa terdapat korelasi antara IPK dengan lama studi dengan nilai UKMPPD. Variabel yang sangat berpengaruh yaitu IPK dengan lama studi.

"Analisis Prestasi Akademik dan lama Studi Mahasiswa Lulusan Jurusan PMIPA FKIP UNTAN ditinjau dari jalur masuk dan program kuliah" oleh Djudin (2018) yang menyatakan bahwa terdapat hubungan antara prestasi akademik dengan lama studi mahasiswa jurusan PMIPA FKIP Untan. "Hubungan Indeks Prestasi Komulatif Dengan Nilai Ujian Komprehensif Mahasiswa Fakultas Tarbiyah dan Ilmu Keguruan IAIN Bukittinggi “ oleh Medika et al. (2019) menyatakan bahwa terdapat hubungan antara Indeks Prestasi Komulatif dengan nilai ujian komprehensif mahasiswa Fakultas Tarbiyah dan Ilmu Keguruan IAIN Bukittinggi. Perbedaan hasil temuan ini mungkin disebabkan oleh banyak faktor, seperti: perbedaan variabel, perbedaan program studi, tempat, mahasiswa, materi/jenis ujian dan lain lain.

Tabel 1. Penjelasan Koefisien Korelasi Nilai r

\begin{tabular}{ll}
\hline \multicolumn{1}{c}{ Interval Koefisien } & \multicolumn{1}{c}{ Tingkat Korelasi } \\
\hline $0.80-1,000$ & Sangat Kuat \\
$0,60-0,799$ & Kuat \\
$0,40-0,599$ & Cukup Kuat \\
$0,20-0,399$ & Rendah \\
$0,00-0,199$ & Sangat Rendah \\
\hline
\end{tabular}

Tabel 2. Uji Normalitas dengan Memakai Uji Saphiro Wilk dengan SPSS

Tests of Normality

\begin{tabular}{lcccccccc}
\hline & \multicolumn{3}{c}{ Kolmogorov-Smirnova } & \multicolumn{3}{c}{ Shapiro-Wilk } \\
\hline & Statistic & df & Sig. & Statistic & df & \multicolumn{2}{c}{ Sig. } \\
\hline Lama Studi & .498 & 43 & .000 & .463 & 43 & .000 \\
Nilai Kompre & .111 & 43 & $.200^{*}$ & & .947 & 43 & .048 \\
\hline a. Lilliefors Significance Correction & & & & \\
*. This is a lower bound of the true significance. & & & &
\end{tabular}


Tabel 3. Uji Hipotesis dengan Memakai Uji Spearman's Rho

\begin{tabular}{llrr}
\hline & & Lama Studi & Nilai Kompre \\
\hline Lama Studi & Correlation Coefficient & 1.000 & -.114 \\
& Sig. (2-tailed) &. & .467 \\
& $\mathrm{~N}$ & 43 & 43 \\
\hline Nilai Kompre & Correlation Coefficient & -.114 & 1.000 \\
& Sig. (2-tailed) & .467 &. \\
& $\mathrm{~N}$ & 43 & 43 \\
\hline
\end{tabular}

Faktor-faktor yang menyebabkan tidak ada korelasi yang signifikan antara lama studi dengan nilai komprehensif mahasiswa, yaitu: kesalahan dalam pengambilan sampel, waktu pelaksanaan ujian komprehensif, materi yang diujikan dalam ujian komprehensif, kesalahan dalam memberikan nilai, kurangnya persiapan mahasiswa untuk mengikuti ujian komprehensif, dan lain-lain. Penelitian ini telah membuktikan bahwa terdapat korelasi yang sangat rendah dengan arah negatif antara lama studi dan nilai ujian komprehensif mahasiswa.

\section{KESIMPULAN}

Berdasarkan hasil penelitian yang didapat, maka dapat disimpulkan bahwa tidak ada korelasi signifikan dengan kategori sangat rendah dengan arah negatif antara lama studi dengan nilai ujian komprehensif wisudawan/ti angkatan XI Program Studi Pendidikan Matematika IAIN Bukittinggi tahun 2019. Disarankan pada peneliti selanjutnya untuk meneliti lebih jauh variabel-variabel lainnya yang mempengaruhi nilai ujian komprehensif.

\section{DAFTAR KEPUSTAKAAN}

Arikunto, S. (2007). Manajemen Penelitian. PT Rineka Cipta.

Asrib, A. R., \& Haedir. (2017). Analisis Hubungan Indeks Prestasi Kumulatif (IPK) Lulusan dan Lama Studi Jurusan Pendidikan Teknik sipil dan Perencanaan Fakultas Teknik Universitas Negeri Makassar. Seminar Nasional Fakultas Teknik Universitas Negeri Makassar.

Djudin, T. (2018). Analisis Prestasi Akademik Mahasiswa Lulusan Jurusan Pendidikan Mipa Fkip Untan Ditinjau Dari Jalur Masuk (Snmptn, Sbmptn, Mandiri) Dan
Program Kuliah (S-1 Reguler, S-1 Percepatan Apk). Jurnal Pendidikan Matematika Dan IPA, 9(2), 76. https://doi.org/10.26418/jpmipa.v9i2.2586 7

Mardi, R. (2018). Hubungan Indeks Prestasi Kumulatif Dan Lama Studi Dengan Nilai Uji Kompetensi Mahasiswa Program Profesi Dokter Peserta First Taker Fakultas Kedokteran Universitas Andalas [Universitas Andalas]. http://scholar.unand.ac.id/id/eprint/32529

Medika, G., Kardena, A., Afrida, Y., \& Tomi, Z. (2019). The Correlation Among Grade Point Average to The Students' Comprehensive Test Score at Faculty of Tarbiyah and Teacher Training IAIN Bukittinggi. https://doi.org/10.4108/eai.17-102019.2289762

Riduwan. (2004). Belajar Mudah Penelitian untuk Guru-Karyawan dan Peneliti Muda. Alfabeta.

Ripkey, Douglas R; Case, Susan M; Swanson, D. B. (1999). Identifying students at risk for poor performance on the USMLE step 2. Academic Medicine, 74(10), S45-8. https://journals.lww.com/academicmedici ne/Abstract/1999/10000/Identifying_stude nts_at_risk_for_poor_performance.36.asp $\mathrm{X}$

Samekto, D., Syafrudie, H. A., \& Sutrisno. (2014). Kecenderungan Lama Studi Dan Prestasi Belajar Mahasiswa Jalur Reguler Dan Non-Reguler Program Studi Pendidikan Teknik Bangunan. Teknologi Dan Kejuruan, 37(2), 153-166.

Sugiyono. (2016). Metode Penelitian Pendidikan Kuantitatif dan Kualitatif dan $R \& D$. Alfabeta.

Tim Penyusun. (2018). Pedoman Akademik IAIN Bukittinggi. LPM IAIN Bukittinggi. 